\title{
Parasitism of the isopod Riggia puyensis Rodríguez-Haro et al. in two armored catfish from Pastaza Province (Ecuador)
}

\author{
SILVIA E. PLAUL ${ }^{1,4}$, CECILIA RODRÍGUEZ-HARO ${ }^{2}$, SERGIO R. MARTORELLI ${ }^{3}$ and CLAUDIO G. BARBEITO ${ }^{4}$ \\ ${ }^{1}$ Servicio de Ictiopatología y Acuicultura, Facultad de Ciencias Veterinarias (FCV), Av. 60 y 118 , \\ s/n, Universidad Nacional de La Plata/UNLP, B1900, La Plata, Buenos Aires, Argentina \\ ${ }^{2}$ Universidad Regional Amazónica IKIAM, Biotecnología, Cátedra de Parasitología, \\ Parroquia Muyuna, Kilómetro 7 vía a Alto Tena, s/n, Tena, Napo, Ecuador \\ ${ }^{3}$ Centro de Estudios Parasitológicos y Vectores (CEPAVE), CCT-La Plata-CONICET- \\ UNLP. Av. 122 s/n, B1900, La Plata, Buenos Aires, Argentina \\ ${ }^{4}$ Laboratorio de Histología y Embriología Descriptiva, Experimental y Comparada (LHYEDEC), \\ FCV Av. 60 y 118 s/n, UNLP, B1900, La Plata, Buenos Aires, Argentina
}

Manuscript received on August 15, 2018; accepted for publication on January 16, 2019

\begin{abstract}
How to cite: PLAUL SE, RODRÍGUEZ-HARO C, MARTORELLI SR AND BARBEITO CG. 2019. Parasitism of the isopod Riggia puyensis Rodríguez-Haro et al. in two armored catfish from Pastaza Province (Ecuador). An Acad Bras Cienc 91: e20180849. DOI 10.1590/0001-3765201920180849.
\end{abstract}

\begin{abstract}
Riggia puyensis, an ectoparasitic isopod, was collected in juvenile Chaetostoma breve and Chaetostoma microps host specimens from the Amazonian region of Ecuador. The aim of this work is to study the possible injury that the parasite causes in its host. $R$. puyensis was found covered by a fold of the skin, which formed a sort of pocket or pouch within the host's peritoneal cavity. The alterations described in the epidermis were associated with the mechanical action of the isopod inside the pouch.
\end{abstract}

Key words: Armored catfish, Cymothoidae, isopod, Riggia puyensis.

\section{INTRODUCTION}

Chaetostoma Tschudi, locally called "carachamas", is a genus of suckermouth armored catfish (Siluriformes: Loricariidae) distributed across the eastern and western slopes of the Andes and in the Guiana Shield (Ballen et al. 2016). In the Pastaza Province, Amazonian region of Ecuador, Chaetostoma breve Regan, 1904 and Chaetostoma microps Günther, 1864 are commonly found in fast-flowing rivers with high oxygen concentration, such as the Pastaza, Curaray, Bobonaza, Arajuno,

Correspondence to: Silvia Elena Plaul

E-mail: splaul@fcnym.unlp.edu.ar

ORCid: http://orcid.org/0000-0001-7318-7863
Anzu, and Puyo rivers. These fishes are used as a food source (Rivadeneira et al. 2010), mostly in the indigenous cuisine, since traditional dishes such as "maitos" and "caldos" are prepared with these species.

During a survey on parasites of the "carachamas" fish, a total of 236 specimens of C. microps and $C$. breve obtained by artisanal fishermen and collected by hand and cast nets were captured from the Amazonian region of Ecuador. Of these, 117 specimens of $C$. microps were collected in the Puyo River $\left(1^{\circ} 35^{\prime} 22^{\prime \prime} \mathrm{S}, 77^{\circ} 54^{\prime} 13^{\prime \prime} \mathrm{W}\right)$ and 119 specimens $(67=C$. microps and $52=C$. breve) in the Bobonaza River ( $1^{\circ} 35^{\prime} 06^{\prime}$ ' $\mathrm{S}, 77^{\circ} 44^{\prime}$ 15 "W) (Fig. 1). When examining macroscopically 


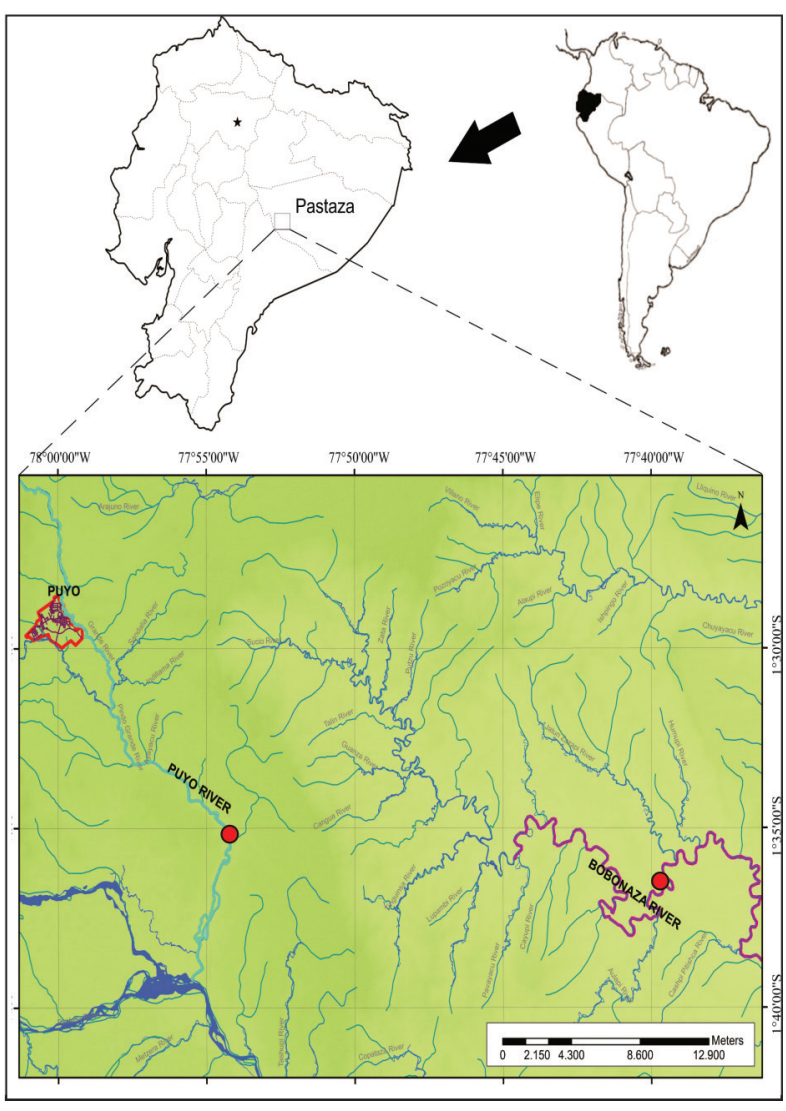

Figure 1 - Map of the sampling sites (red points) for collection of "carachamas" (Chaetostoma breve and Chaetostoma microps) in Amazonian region of Ecuador, Puyo and Bobonaza rivers.

to the fishes, an isopod parasite was observed. The crustacean was found in the peritoneal cavity, with only a small hole that allowed it to breathe. The objective of this work is to study the possible injury or damaging effects that the parasite causes in its host.

\section{MATERIALS AND METHODS}

The infected specimens were euthanized by anaesthetic overdose and the whole fish were fixed by immersion in $10 \%$ buffered formalin. In the laboratory, fish were weighed and the total length recorded. The handling, collection and sacrificed process of all individuals followed the guidelines of the American Fisheries Society (A.F.S. 2004). The external body surface of each fish was examined for parasites and only the parasitized specimens were sacrificed. Some isopods were removed from the host abdominal region for a posterior identification. According to the characteristics described by Rodríguez-Haro et al. (2017) as a large female size; presence of developed eyes; pleotelson sharp; orientation and conformation of mandible and palp; presence of plumose setae in maxilliped; maxilla with hairs and scales; spined antennule with seven segments; and morphology of maxillule, pereopods and pleopods, these specimens were assigned to Riggia puyensis (Isopoda, Cymothoidae). The isopods studied now, are part of the original material used by RodríguezHaro et al. (2017) for the description of R. puyensis. The original specimens used for the descriptions where deposited in the collection of the Museo de La Plata, Argentina (MLP) by Rodríguez-Haro et al. (2017) (Holotype MLP 27154 and Allotype MLP 27155), representative material was selected for light microscopic studies. First, the fixed fishes were decalcified with ethylene diamine tetra acetic acid (EDTA) CAS (6381-92-6) Biopack, Argentina and were routinely processed and embedded in paraffin wax (Plaul et al. 2017). Histological sections were cut by sledge microtome, prepared according to standard protocol, and then stained with hematoxylin and eosin technique. Microphotographs were taken with an Olympus microscope, CX31 equipped with an Olympus camera U-CMAD3 (Tokyo, Japan).

Of the total number of specimens examined, only seven were parasitized with $R$. puyensis. All the isopods were found in a pouch within the abdominal cavity of juvenile "carachamas", with standard lengths being $11.33 \pm 9.91 \mathrm{~cm}$ and $19.65 \pm$ $2.83 \mathrm{~cm}$ for $C$. microps and C. breve, respectively. Parasites showed no preference for sex of host. The necropsy revealed that each of the parasitized fish had a single female isopod that maintained an opening towards the outside through a small pore of 3-5 $\mathrm{mm}$ in diameter (Fig. 2a). These pores were 


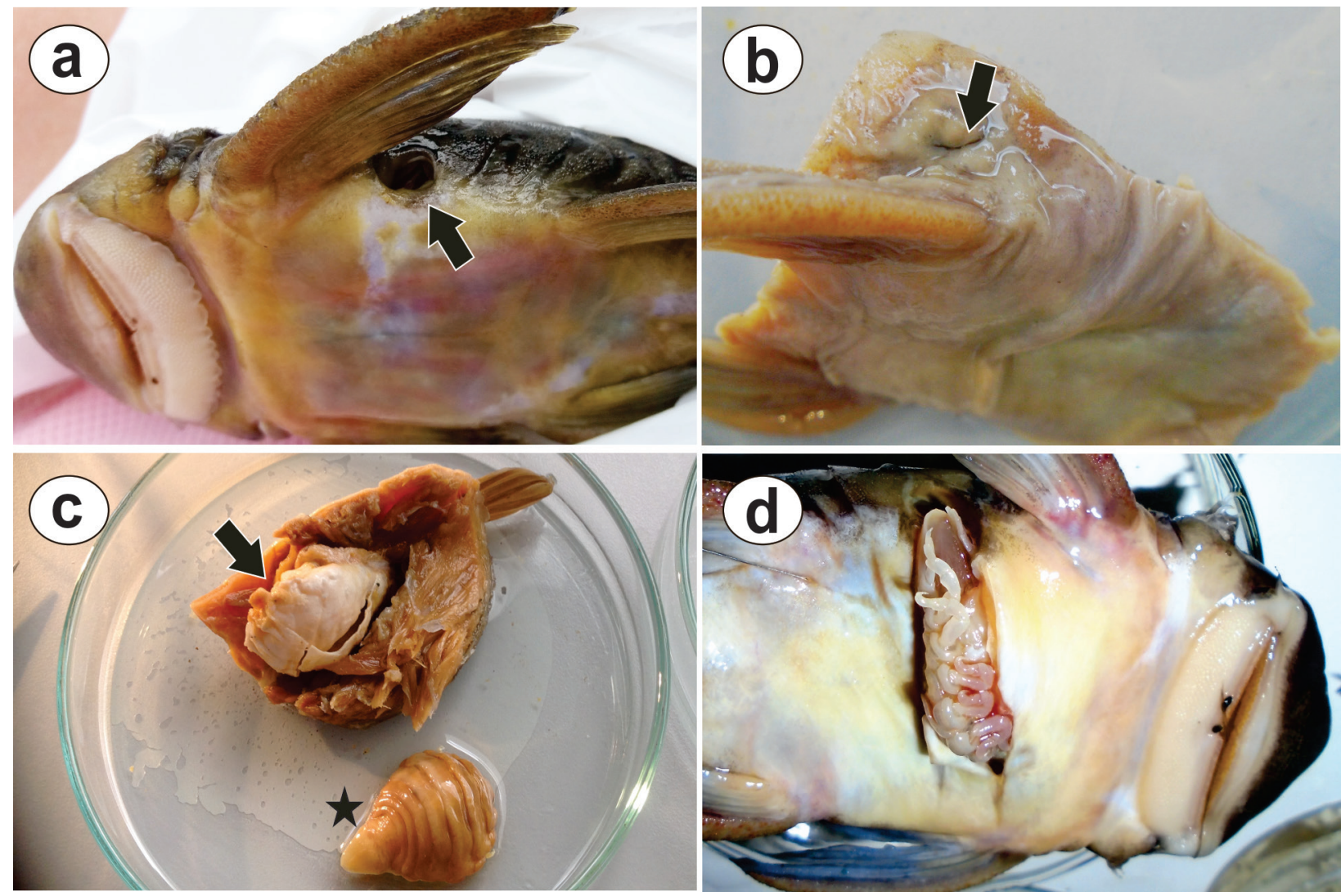

Figure 2 - a. Specimen of Chaetostoma breve shows a pore (arrow) on the lateral flank. b. Obliteration of the pore, giving rise to a scar (arrow). c. The skin (arrow) that forms a sort of pocket or pouch in the abdominal cavity of the fish. Female of Riggia puyensis, dorsal view (star). d. Position of the crustacean in the abdominal cavity, with the pleotelson showing its caudal tip through the pore.

located on the lateral flanks, behind the pectoral fins, or between the pectoral and pelvic fins, indistinctly on the right or left sides. Although the parasitized fish were juveniles, it was also observed in four adult fish $(>25 \mathrm{~cm})$, in the same place previously described a mark similar to a scar (Fig. 2b). When the necropsy of these specimens was performed, neither parasites nor empty exoskeletons were found. Each specimen of $R$. puyensis was found covered by a fold of skin, which formed a pocket or pouch (Fig. 2c), with the cephalon towards the cranial region of the host fish and the pleotelson showing its caudal tip through the pore (Fig. $2 d)$. The internal organs of the fish showed no macroscopic damage, but the stomach, liver and intestine appeared slightly displaced and adapted to the abdominal cavity generated by the parasite's presence; the peritoneum was intact.

The histological analysis of the cross sections at pore level confirmed that the pouch was formed by epidermis and dermis (Fig. 3a), keeping the parasite and the host in separate environments; no secondary infections could be observed. In the dorsal region of the isopod, at pereonite level, the pouch epidermis was absent and there was a decrease in the number of melanophores (Fig. 3b), probably due to the mechanical action of the parasite. At both ends of the pereonites (Fig. 3a, c), atrophy of the pouch epidermis was observed, in such sites, flat cells were arranged in few layers and mucous cells were absent. In the ventral region of the isopod, where the pereopods were located, the pouch epidermis presented an 

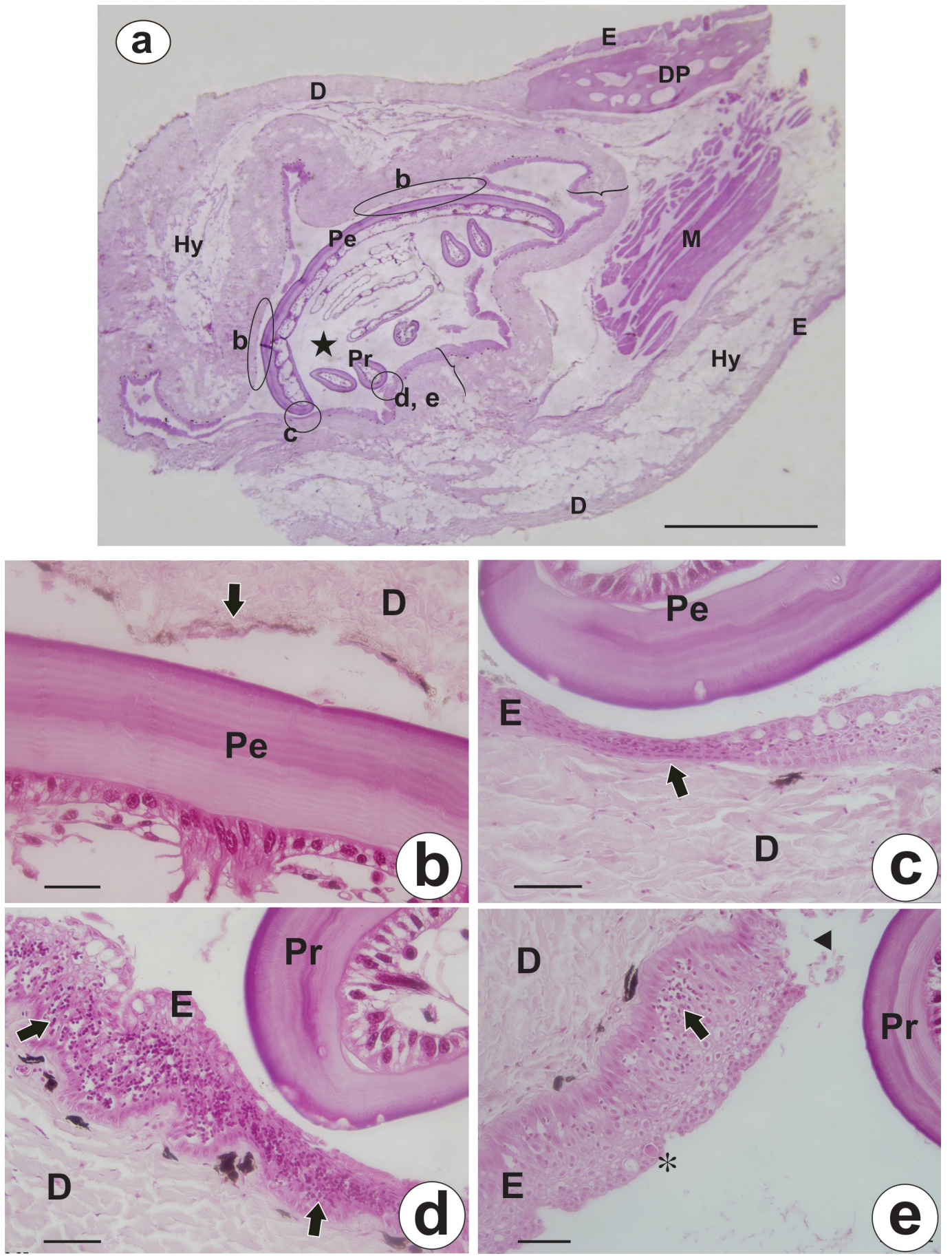

Figure 3 - a. Cross section at pore level showing the pouch, formed by epidermis and dermis (curly brackets), and inside the parasitic isopod (star), the circles (b - e) show the friction sites of the parasite. Scale bar: $2 \mathrm{~mm}$. $\mathbf{b}$ - e. Detail of the friction sites. b. Dorsal region of the isopod, at pereonites level, pouch epidermal tissue is absent (arrow) and a decrease in the number of melanophores is observed. c. End of the pereonite, atrophy of the pouch epidermis was observed (arrow). d. e. At pereopods level, an increase in the height of the pouch epithelium is observed and an intense cellular infiltration, mainly lymphocytes (arrows), a few eosinophilic granular cells (asterisk) and desquamation of the epidermal tissue (head arrow). Scale bar: $50 \mu \mathrm{m}$. D: dermis, DP: dermal plates, E: epidermis, Hy: hypodermis, M: musculature, Pe: pereonites, Pr: pereopods. 
increase in the height of the basal stratum, together with a pronounced infiltration of inflammatory cells, mainly lymphocytes and a few eosinophilic granular cells (Fig. 3d, e). Furthermore, in certain sectors, a desquamation of the epidermal tissue was evident (Fig. 3e).

In Ecuador, few members of the family Cymothoidae have been recorded as parasites of "carachamas", among them Riggia sp. in Chaetostoma sp. (Anaguano-Yancha and Brito 2015), Artystone trysibia Schioedte, 1866 in Chaetostoma dermorhynchum Boulenger, 1887 (Junoy 2016) and R. puyensis in C. breve and C. microps (Rodríguez-Haro et al. 2017). In general, fishes were not affected, except for the tissue damage within the pouch resulting from the mechanical action of the chitinous parts of the parasite, as has been observed by other researchers, such as Schaefer (1993) and Öktener et al. (2018). Moreover, there was an obvious displacement of internal organs generated by the pressure of the parasite within the abdominal cavity. Several researches have reported histological changes on the epidermis characterized by erosion, desquamation, atrophy and infiltration of inflammatory cells (Romestand et al. 1977, Rand 1986, Adlard and Lester 1995, Rameshkumar and Ravichandran 2013). In our study, the marks observed at the pore site in specimens with a length of more than $25 \mathrm{~cm}$ could corroborate that at the death of the female the pore obliterates, leaving a scar. According Trilles (1986), Adlard and Lester (1995), Charfi-Cheikhrouha et al. (2000) and Fogelman and Grutter (2008) parasitized adult fish might lose their parasites and the death of isopods it would be indicated by empty exoskeletons or by scars. Brusca (1981) reported that cymothoids females could live one year or occasionally two years, but Williams and Bunkley-Willians (1982) and Maxwell (1982) suggests that some species can live for a long period of time inclusive up to nine years on a host. Many of cymothoids attaches to the fish in their juvenile stages, and that the growth of both the host and the isopod occur simultaneously (Bunkley-Willians 1984, Adlard and Lester 1995, Alvarez and Flores 1997, Bunkley-Willians and Willians 1998). Also, de Souza Azevedo et al. (2006) suggested this growth pattern seems to be a natural strategy that would increase their reproductive performance. According to our observations, this synchrony in the attachment and growth of $R$. puyensis would explain how the isopod is covered by a skin fold without causing severe damage to the tegument or internal organs. Therefore, we do not consider that $R$. puyensis is covered by a true capsule, secreted by the host, as it occurs in other parasites.

\section{CONCLUSIONS}

In conclusion, a single female of $R$. puyensis was found in a pouch occupying a large part of the host abdominal cavity. Although the peritoneum was intact, this disposition has as a consequence the displacement of the liver, stomach and intestine inside the cavity which could affect the efficiency of its function. The alterations described in the epidermis as erosion, desquamation, atrophy and infiltration of inflammatory cells were associated with the mechanical action of the isopod inside the pouch. In this case, we do not consider the pore to be a gateway to secondary infections or bacterial diseases, because the host epidermis and dermis forming the pouch would act as an effective barrier.

\section{AUTHOR CONTRIBUTIONS}

S. E. Plaul: histopathology preparation, pathological analysis and writing. C. Rodríguez-Haro: field sampling methodology. S. R. Martorelli: taxonomic identification and supervision. C. G. Barbeito: pathological analysis and writing.

\section{REFERENCES}

ADLARD RD AND LESTER RJG. 1995. The life cycle and bilogy of Anilocra pomacentri (Isopoda, Cymothoidae), and ectoparasitic isopod of the coral-reef fish Chromis 
nitida (Perciformes, Pomacentridae). Aust J Zool 43(3): 271-281.

AFS - AMERICAN FISHERIES SOCIETY. 2004. Guidelines for the Use of Fishes in Research. Bethesda, MD.

ALVAREZ F AND FLORES M. 1997. Cymothoa exigua (Isopoda: Cymothoidae) parasitando al pargo Lutjanus peru (Pisces: Lutjanidae) en Manzanillo, Colima, México. Rev Biol Trop 44(1): 391-394.

ANAGUANO-YANCHA F AND BRITO J. 2015. Parasitismo de Riggia sp. (Isopoda: Cymothoidae) en dos especies de peces Chaetostoma sp. y Rhamdia quelen del suroriente del Ecuador. Av Cienc Ing (Quito) 7(1): B13-B16.

BALLEN GA， URBANO-BONILLA A AND MALDONADO-OCAMPO JA. 2016. Description of a new species of the genus Chaetostoma from the Orinoco River drainage with comments on Chaetostoma milesi Fowler, 1941 (Siluriformes: Loricariidae). Zootaxa 4105(2): 181-197.

BRUSCA RC. 1981. A monograph on the Isopoda Cymothoidae (Crustacea) of the eastern Pacific. Zool J Linn Soc 73: 117-199.

BUNKLEY-WILLIANS L. 1984. Geographic distribution and early life history of Anilocra (Isopoda: Cymothoide) parasites of coral reef fishes. Ph.D. Dissertation. Auburn Universitu, Auburn, Alabama, p. 141.

BUNKLEY-WILLIANS L AND WILLIANS EH JR. 1998. Isopods associated with fishes: a synopsis and corrections. J Parasitol 84(5): 893-896.

CHARFI-CHEIKHROUHA F, ZGHIDI W, YARBA OL AND TRILLES JP. 2000. Les Cymothoidae (Isopodes parasites de poisons) des Côtes Tunisiennes: Écologie et indices parasitologiques. Systematic Parasitol 46: 143-150.

DE SOUZA AZEVEDO J, GOMES DA SILVA L, SILVEIRA FONTENELLE BIZERRIL CR, ALENCAR DANSAPETRETSKI M AND REJANE WILLE LIMA N. 2006. Infestation pattern and parasitic castration of the crustacean Riggia paranensis (Crustacea: Cymothoidea) on the fresh water fish Cyphocharax gilbert (Teleostei: Curimatidae). Neotrop Ichthyol 4(3): 363-369.

FOGELMAN RM AND GRUTTER EAS. 2008. Mancae of the parasitic cymothoid isopod, Anilocra apogonae: early life history, host-specificity, and effect on growth and survival of preferred yound cardinal fishes. Coral Reefs 27: 685-693.

JUNOY J. 2016. Parasitism of the isopod Artystone trysibia in the fish Chaetostoma dermorhynchum from the Tena River (Amazonian region, Ecuador). Acta Trop 153: 36-45.
MAXWELL JGH. 1982. Infestation of the jack mackerel, Trachurus declivis (Jenyns) with the cymothoids isopod, Ceratothoa imbricatus (Fabricus), in south eastern Australian waters. J Fish Biol 20: 341-349.

ÖKTENER A, TRILLES JP AND ALAŞ A. 2018. Elthusa poutassouiensis (Penso 1939), comb. nov. (Isopoda: Cymothoidae) for Meinertia (Ceratothoa) poutassouiensis, parasite of the blue whiting, Micromesistius poutassou. Bull Eur Ass Fish Pathol 38(1): 12-23.

PLAUL SE, ANDRÉS LAUBE PF, PAHECO MARINO SG, SANTAMARÍA MARTÍN CJ, MOYANO DA AND BARBEITO CG. 2017. Morphological techniques used in ichthyopathological diagnosis. In: Microscopy and imaging science approaches to applied research and education. A. Méndez-Vilas Eds. Zaragoza, España, p. 269-280.

RAMESHKUMAR G AND RAVICHANDRAN S. 2013. Histopathological changes in the skin and gills of some marine fishes due to parasitic isopod infestation. J Coastal Life Med 1(1): 74-80.

RAND TG. 1986. The histopathology of infection of Paranthias furcifer (L.) (Osteichthyes Serranidae) by Nerocila acuminata (Schioedte and Meinert) (Crustacea: Isopoda: Cymothoidae). J Fish Dis 9(2): 143-146.

RIVADENEIRA JF, ANDERSON E AND DÁVILA S. 2010. Peces de la Cuenca del Pastaza. Fundación Natura, Quito Ecuador, p. 62.

RODRÍGUEZ-HARO C, MONTES MM, MARCOTEGUI P AND MARTORELLI SR. 2017. Riggia puyensis n. sp. (Isopoda: Cymothoidae) parasitizing Chaetostoma breve and Chaetostoma microps (Siluriformes: Loricariidae) from Ecuador. Acta Trop 166: 328-335.

ROMESTAND B, JANICOT M AND TRILLES JP. 1977. Modifications tissulaires et reactions de defense chez quelques téléostéens parasites par les Cymothoidae (Crustacés, Isopodes, Hématophages). Ann Parasitol Hum Comp 52: 171-180.

SCHAEFER SA. 1993. A remarkable occurrence of isopod parasitism on an armoured catfish, Microlepidogaster maculipinnis. J Fish Biol 42: 307-310.

TRILLES JP. 1986. Les Cymothoidae (Crustacea, Isopoda, Flabellifera) d'Afrique. Bull Mus Natl Hist Nat B Adansonia 3: 617-636.

WILLIANS EH JR AND BUNKLEY-WILLIANS L. 1982. Mothocya bohlkeorum, new species (Isopoda: Cymothoidae) from west Indian Cardinal fishes (Apogonidae). J Crustacean Biol 2(4): 570-577. 